\title{
The Teachers' Roles in Reducing the Interference of L1 in Audio-lingual Classrooms: A Qualitative Case Study in Malaysian Primary School
}

\author{
Mohammad Naim Rahim ${ }^{1^{*}} \&$ Sayed Ali Reza Ahmadi ${ }^{2}$ \\ ${ }^{1}$ Kunduz University, Kunduz. Afghanistan \\ ${ }^{2}$ Universiti Teknologi Malaysia, Johor Bahru. Malaysia \\ mnaim.rahim@gmail.com
}

\section{ARTICLE HISTORY

$\begin{array}{ll}\text { Received } & : 2021-03-14 \\ \text { Revised } & : 2021-08-15 \\ \text { Accepted } & : 2021-08-19\end{array}$

\section{KEYWORDS}

L1

$L 2$

Teachers'

Audio-Lingual Method

Role Model

Orchestra Leader

Motivator

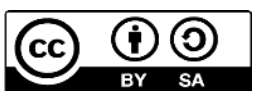

\begin{abstract}
This research article explores the teachers' roles in reducing L1 (First Language) interference in audio-lingual classrooms. The main concern of the audio-lingual method is to focus less on grammar and teaching it inductively. There is also an emphasis on pronunciation in this method. Using tapes, visual language aids, and new materials are presented in an interactive model. The teacher presents a new structure using communicative models, and there is less focus on L1. The study applies a qualitative case study and uses observation and interview data collection techniques in a particular primary school of Malaysia during the English language sessions. The thematic analysis technique is performed to categorize the significant findings into three main themes: teacher as a role model, teacher as an orchestra leader, and teacher as a motivator. The data from classroom observation is triangulated to determine how the data is closed to the interview. The finding shows the problems of using L1 in teaching L2 (Second Language) since the interference of L1 negatively impacts learning L2. The study contributes to the perspective that English teachers in audiolingual classrooms are expected to understand their objective roles. The result also implies the teachers' significance to accept that using L1 in maxim spoils learning L2, especially in an audio-lingual classroom.
\end{abstract}

\section{Introduction}

The concept of foreign language teaching and learning has emerged broadly in the world today. Teaching English as one of the international languages has been divided into many other subbranches, like teaching English as a foreign language (EFL) or teaching English as a second language (ESL). It is currently discussing traditional or modern language teaching methods and the use of postmethods and 21st-century learning modules in EFL education (Rahim, 2021). In primary time, language teaching methodology (LTM) has also become an issue for most institutions where language teaching and learning is a cornerstone. Indeed, the $21^{\text {st }}$ century is the age of intelligence and meaningful communication where mostly the political, economic, or cultural borders do not matter (Harari, 2019). As such, communities across the world seek better ways to communicate effectively. In this regard, the concepts of teaching language and how to teach a foreign language have become a great business and attractive educational phenomenon globally. However, while language teaching methodology is focused, traditional methods align with e-learning in language teaching classrooms, even during the COVID-19 pandemic. One of the typical traditional methods in schools and universities is the audio-lingual method which needs further investigations to address its potentials and limitations in foreign language classrooms.

Initially, the theory of underlying language audiolingualism is derived from the Structural Approach to language, which is developed by Fries in the 1950s. Saricoban (2016) has also indicated that structural linguistics is a reaction to the traditional approaches which have linked the study of language to philosophy. According to Nita and Syafei (2012), it is not easy for students to communicate English. They have to think more when speaking because they need to produce the correct sentences and appropriate words, even with good pronunciation. Since students are exposed to learn the English language in the context of $\mathrm{L} 1$, on the other hand, there is a classic perception of learning a second language interfering with L1. Indeed, without using the second language in an authentic way of communication, it is impossible to learn it, primarily if L1 is used in a second language classroom. Therefore, this particular case study intends to explore the roles of teachers in reducing the interference of L1 in an audio-lingual classroom. 
In addition, Hashemi and Kew (2020) indicated that English teachers must focus on teaching the English language rather than teaching about the English language using L1 in the language learning process through blended learning approaches. Indeed, using traditional methods of language teaching and learning facilitate teachers to teach about language. English language textbook evaluation also shows that there is always an emphasis on teaching specific skills in language classrooms, which focuses less on students' communication competence. A study in terms of the skills in English textbooks indicate that it covers all four skills of language learning, but the evaluation shows a considerable focus on reading, grammar, and vocabulary (Rahim, Mohammadi, \& Hashemi, 2021). However, the integration of technology enhances this objective as teaching the English language is to communicate efficiently. Learners can make themselves understood and use their current proficiency to the fullest through the use of social media and ICT potentials since the growing technology of the world is transforming the paradigms, including the students' needs, the layout of the classrooms, and the stakeholders' requirement for employability (Rahim \& Zare, 2021).

According to Hornby (2000), teaching means instructing, providing learners with the knowledge, skill, and language input. Hence, teachers should potentially motivate the learners to interact using their obtained knowledge and skills of the language. Besides, Burnkart (1998) stated that language learners should avoid confusion due to faulty pronunciation, grammar, or vocabulary and observe the social and cultural rules in each communication context. Since the interference of L1 in a second language classroom damages the social and cultural aspect of the language and abuses the fact that language is purely learned byproduct of language itself. Therefore, the interference of L1 in learning L2 will reduce the production of a second language.

This reality makes teachers think of how using target language teaching ability could be mastered and applied in the classroom. Many students are still afraid of using English, and even they cannot speak English in Malaysia (Badrasawi et al., 2020). The reason for using $\mathrm{L} 1$ accordingly by the instructors as a tool is to make sure that the students learn about the language. It does not work while the purpose of second language teaching and learning is to develop communicative competencies. When the teachers produce L1 in the classroom, students face a lack of L2 input to produce the appropriate language. They feel a lack of vocabulary, sentence structures, oral communicative skills, and pronunciation.

In contrast, the teacher can teach pronunciation through various activities to engage the student in using L2. The audio-lingual method is one way to solve this problem. This method can drill students in the use of grammatical sentence patterns. Richards and Rodgers (2001) also stated that the audio-lingual method advises that the students are taught a language directly without using their native language to explain new words or grammar in the target language.

Thus, teaching English as a second language improves learners' communicative skills and produces the language appropriately. The audio-lingual method does not focus on teaching vocabulary but the teacher drills the student in using grammar and pushes the students to parrot the utterances spoke out by the teachers to train their pronunciation. According to Nita and Syafei (2012), in an audio-lingual method, the teacher's role is central and active; it is a teacherdominated method. The teacher models the target language, controls the direction and pace of learning, monitors and corrects the students' performance. The teacher is also responsible for providing the students with a good model for imitation because the students are imitators of the teacher's model. According to Saricoban (2016), the teacher's role is teacherdominated because the teacher becomes a model like a native speaker and the students have to repeat what their teacher says. Therefore, the students follow the teacher's directions and respond accurately and as rapidly as possible.

The results of a study by Mohammadi et al. (2019) also indicated that the majority of the teachers in the primary schools of Malaysia switch to students' L1 to accommodate low proficiency learners and explain complex concepts such as grammar and vocabulary to the learners. According to this study, 80 per cent of the participant agreed to minimize the interference of L1 in second language learning classrooms. Since L1 is a barrier to learning L2, it also prevents the student from acquiring valuable input in the L2 (Krashen \& Terrell, 1983). The study also shows a research gap that there is a lack of teachers' understanding in the primary schools of Malaysia to focus on their potential roles in reducing the interference of $\mathrm{L} 1$ in teaching L2. As a result, it is crucial to explore the teachers' roles in reducing the interference of L1 in an audio-lingual classroom. This will provide an accurate understanding for EFL and ESL teachers to focus on their potential roles in teaching L2 by applying the audio-lingual method.

Therefore, this particular study applies a qualitative case study to address the objectives and fulfil the research gap in exploring the teachers' roles in reducing the interference of L1 in learning L2 using the audio-lingual method. This qualitative case study is conducted since the research design enables the study in exploration of the issue within Malaysian Primary School through various data sources in this case (observation and interview) and it undertakes the exploration through a variety of lenses to reveal multiple facets of the phenomenon (Creswell \& Poth, 2017). This research method also helps in generating an in-depth, multi-faceted understanding of the 
teachers' roles in reducing the interference of L1 in learning L2 in the real-life context.

The participants are English language students and the teacher who are purposefully selected from a particular primary school in Malaysia. According to Elmusharaf (2012), the purposeful sampling technique is broadly used in qualitative research to identify and select an in-depth understanding of the cases related to the perspectives of the discipline practitioners. Classroom observations (field notes) and interviews are used as data collation techniques. According to Creswell and Poth (2017), field observations and interviews are techniques where the researcher/s observes and investigates the participants in real locations and situations, such as workplaces, homes, and institutions (Malaysian Primary School). These techniques help the study to understand the participants' behaviour, habits, needs, social relations, and perceptions in their teaching and learning environment.

The data analysis technique is thematic since thematic analysis aims to code, pattern, categorize, and identify the themes in the crucial data and use these themes to address the research (Clarke \& Braun, 2013). This is much more than simply summarizing the data; an excellent thematic analysis interprets and makes sense of it. Therefore, thematic analysis is performed to answer the main research questions; $\mathbf{1}$. What are the teachers' roles in an audio-lingual classroom? 2. How to reduce the interference of L1 in learning L2? This also contributes to enriching the body of existing literature as well as provides an indepth understanding of the teachers' roles in reducing the interference of L1 in learning L2 using the audiolingual method for educators in the field and language experts.

\section{Literature Review}

\subsection{What is Audio-Lingual Method?}

Many studies in language teaching and learning have indicated that no single method is proper rather an integration of approaches. Each language teaching and learning method, including traditional methods and e-learning, has its barriers and opportunities. As Rahim and Sandaran (2020) indicated that eLearning is said to enhance EFL education, there are still barriers and opportunities for the use of this approach that needs to be investigated. Therefore, English teachers, training experts, language professionals, and linguists in Malaysia should realize to use which method while teaching English as a second or foreign language. One of the methods initiated in the mid- $20^{\text {th }}$ century is audio-lingual. According to LarsenFreeman and Anderson (2018), the audio-lingual method urges students to drill short patterns and many other interactions where students are supposed to listen, repeat, and memorize. The researcher focuses on creating outputs for learners in dramatic ways to member the inputs based on music, imitation, and drills.

On the other hand, some studies have investigated that the audio-lingual method has been extracted from linguistic and psychological theories. For example, Brown (2001) indicated that mimicry drills and pattern practices are the two leading psychological indicators by which learners could effectively comprehend the outputs. Therefore, the audio-lingual method is recognized as the scientific method developed by enhancements in psychology and linguistics (Rahim, 2021). Hence, audio-lingual substitution drills are mechanical exercises that reinforce structural patterns and practice. For instance, the teacher repeats a dialogue sentence. Then the learners supply a prompt.

Moreover, the environment of the class is a significant variable using the audio-lingual method. Tavakoli (2017) stated that creating a secure and relaxed class environment where students never feel threatening leads to successful learning outcomes. Class management, seating arrangement, sight, and design also play a pivotal role in learning and teaching. Despite the replacement of the audio-lingual method by up-to-date methods such as communicative language teaching (CLT) and its by-products approaches, the current study has shown that the audio-lingual method still functions better in EFL and ESL classrooms. Since the children are keen to learn communicatively via gestures, music, repetition, and group work in the primary schools of Malaysia (Mohammadi et al., 2019). Besides other contextualized methods, the audio-lingual method also assists primary school children to learn using the teacher's body language, picture description, and drills (Larsen-Freeman \& Anderson, 2018).

\subsection{Reducing the Interference of $\mathrm{L1}$ in Learning L2 using Audio-lingual Method}

Audio-lingual is a method by which second language (L2) teachers could reduce students' first language (L1) in a second language classroom. This approach seemed to be effective since students are pushed to use L2 purposefully. However, there are many debates on using L1 in L2 classrooms, either by teachers or students (Mohammadi et al., 2019). Many interconnected factors, such as culture, context, setting, and aptitude, have dramatically come in as various variables, including or excluding the L1 in teaching and learning L2. According to Phillipson (1994), sometimes English teachers teach an Englishonly classroom for political or practical agendas where students vividly experience the complete exclusion of L1. Such concepts ignore bilingual education theories, as Pennycook (1994) also explained that the concept of bilingual education nowadays seems to be not sufficient and is no longer effective. 
As English language educators, we had also experienced the situation when our students used L1 (Persian) in our English classes at the universities of Afghanistan. They naturally quit using L2 (English). We believe that once students use L1, they perpetuate it naturally and ignore speaking in L2. A study on the blended learning approach in EFL education indicates that using L1 in L2 classes could endanger teachers' knowledge. Phillipson (1994) stated that if a teacher uses L1 in teaching an L2, there is a risk of having higher L1 communicative competence by the students where the teacher's abilities to control the class and arguments could be diminished. One of the remarkable notions that belief in maximum use of L2 is the relationship between L2 comprehensible input and L2 proficiency (Krashen, 1985). According to Krashen (1985), any part of L2 should be taught and learned communicatively. Since the more the students are exposed to L2 communication, the more they are aware of language production.

\subsection{Problematisation of Using L1 in Learning L2}

There are many debates whether the first language (L1) has a dominant role in learning a second language (L2). For instance, Mitchell and Myles (2004) stated that learning L2 is extensively different from L1. They believe that each language possesses its own syntactic, semantic, cultural, and contextual connotations. Therefore, learners should learn L2 within their values. In the context of Malaysian primary schools, the English language is taught through the influence of L1. However, students should be qualified for MUET, the Malaysian University English Test that helps schools prepare for university admissions. Thus, it is crucial to explore the teachers' roles in reducing the interference of L1 in an audiolingual classroom to provide an authentic understanding of the issue in primary schools of Malaysia.

From the behavioristic perspective, L1 plays both positive and negative roles in learning L2, but more focus is on the opposing side. For example, Ellis (1994) stated that most errors made by L2 learners cause using L1 as a source of content. Learners directly translate the concepts with the same collocations and connotations, even sometimes with the same cultural values. These adaptations defunctionalise L2 language awareness.

Moreover, there are some theoretical concepts in second language acquisition on the disadvantages of using L1 in learning L2. These concepts vividly show the importance of L2 isolated from L1. One of the influential pioneers in this field is Krashen (1985), whose Monitor Model's Theory suggests five concepts about learning a second language:

a) The Acquisition-Learning Hypothesis

b) The Natural Order Hypothesis

c) The Monitor Hypothesis d) The Input Hypothesis

e) The Affective Filter Hypothesis

First, the acquisition-learning hypothesis states that adults can develop competence in a second language in two distinct and independent ways: acquisition and learning. While the acquisition is a subconscious process in which learners acquire a language 'naturally' through authentic communication; and learning is conscious that refers to developing formal knowledge of a language. According to Krashen (1985), like children, adults still can acquire a second language.

The natural order hypothesis claims that grammatical structures are acquired in a predictable order (Krashen \& Terrell, 1983). The monitor hypothesis explicitly states that L2 learners depend only on the acquired system to generate utterances and that conscious learning can only be used as a monitor to make changes to the utterances generated by the acquired system, either before or after they are produced. Furthermore, monitor use is said to be very limited since three requirements have to be met to use the monitor: (1) the learner has enough time; (2) the learner is thinking about correctness; (3) the learner knows the rule. While the monitor hypothesis indicates a central role for acquisition in developing second language competence, the input hypothesis answers how acquisition takes place. It states that acquisition occurs when acquirers understand input that is a little beyond their current level of competence. They can move from stage I to the next stage, I + 1 , by understanding input containing $\mathrm{I}+1$ (i represents their current competence). The affective filter hypothesis says that attitudinal factors, such as motivation, relate to subconscious language acquisition and that learners with optimal attitudes will obtain more input and acquire more.

In addition, Krashen and Terrell (1983) recognized that the L1 could be used as a short-term solution to meet the immediate needs of learners in L2 communication before they acquire sufficient L2 competence, they acknowledged that falling back on the L1 could have a negative influence on L2 learning, for example, errors emerging as a result of the inconsistency between the L1 and L2 rules. Furthermore, unlike behaviourists who claimed that interference was caused by the negative transfer of learners' knowledge of their L1, Krashen and Terrell (1983) adopted Newmark's ideas. They interpreted interference as the result of a strategy for communication that learners used when they did not have sufficient knowledge of the L2. They also believed that the disadvantages of falling back on the L1 outweighed the advantages in the long run.

Moreover, the cure proposed by Krashen and Terrell (1983) for interference, the acquisition, is coming only from comprehensible input. This seems to indicate that the primary responsibility for L2 
teachers in their teaching is to provide sufficient comprehensible L2 input. They further explained that L1 interference occurred because the second language performers have to talk "too early" before having the time and input to build enough competence to use acquired competence (Krashen \& Terrell, 1983). Therefore, to overcome L1 interference, they suggested that learners should wait for sufficient competence to build up through input before communicating in the L2 rather than using the L1 as a temporary substitute; that is, the L2 should be acquired separately from learners' L1 to avoid the negative influence of the L1. Krashen's (1985) view that input at the appropriate level of difficulty is sufficient for L2 acquisition to take place has been regarded as inadequate in more recent theories.

\section{Method}

The study has applied a qualitative case study using observations and interview data collection techniques. This type of study aims to understand the subject being studied (Creswell \& Poth, 2017). The sample size is kept into one class observation during three sessions to spend more time and extract more accurate information regarding the teachers' roles in reducing the interference of L1 in an audio-lingual classroom. According to Creswell and Poth (2017), a small sample size still adds credibility to the sample when a potential purposeful sample is to consider his/her motivation for participation. The sampling method, therefore, is purposeful sampling.

The participant of the study is an English teacher and students in Sekolah Kebangsaan Nusa Perintis (1), Gelang Patah, Johor, Malaysia. This school is located in a rural area and is established in 2003. Since the study is a part of the Master Degree Project, the school is introduced with an official letter by the Universiti Teknologi Malaysia, where the researchers pursue their postgraduate studies. The teacher has been teaching English for three years. The teacher graduated from one of the teacher training colleges in Malaysia to teach English as a Second Language (TESL). This research is conducted among Year 2 Gamma school students. Their proficiency level is intermediate. They also came from a rural area, and their mother tongue is Malay.

This qualitative case study has executed an observation checklist and structured interview as a data collection technique. The observation checklist is adapted from Christine (2007) that suits the topic of the study as Nunan (1992) indicated that there is no substitute for direct observation as a way of finding out about language in classrooms. The observation checklist contains aspects based on the roles of the teacher in the audio-lingual classroom. The structured interview, according to McDonough and McDonough (1997), performs well as the principal research tool for gathering information about what respondents know, which in this study is used to get accurate information about the teacher's opinion and the teachers' roles in reducing the interference of $\mathrm{L} 1$ in the audio-lingual classroom. The researcher determined the interview questions before the interview session. This is to get the information from the teacher's point of view of the topic. The interview session is conducted after the observation sessions.

The data collection is carried out during the English language period. The duration of the class is 60 minutes. The checklist contains aspects based on the three prominent roles of the teachers in the audiolingual classroom. The adapted checklist is given to three different observers. The observers have observed the observable behaviour of the teacher and filled in the information in the checklist form. The data is collected utilizing non-participant observation since being a non-participant observer allows the researchers to sit back and record what transpired in the whole class without disrupting the natural environment of the classroom (McDonough \& McDonough, 1997). A video recorder was used to record the classes observed.

After the observation, an interview was carried out to get insight information from the teacher. The interview questions are also focused on three main roles of the teacher in the audio-lingual method. The interview session is audio/video recorded so that the researchers collected the best data from the teacher. It is also to ensure the data collected is genuine and no irrelevant information is added. Essentially, the multiple sources of data or the use of mixed methods enhance the credibility of a research study by triangulation (Creswell \& Poth, 2017). The audio and video of the observation and interview are transcribed to analyze the data.

The data from three classroom observations are compared to determine how the data is relevant to the interview. This is done to ensure the data from observation is consistent and valid. After that, the data from both instruments, observations checklist, and interviews are triangulated. Findings from the different sources are validated through a triangulation process (Miles \& Huberman, 1994). The researchers compared both data in a table form to find the similarities between the teacher's beliefs and classroom practices. This is to find the emerging themes from both sources of data. The data of the study are categorized into three main themes based on the roles of the teacher in reducing the interference of L1 in an audio-lingual classroom.

\section{Findings and Discussions}

Based on the transcription and analysis of the data from observation and interview in an audio-lingual classroom, the findings and discussions from both data sources are compared to ensure the triangulation process. The result is also thematically discussed into three main themes: teacher as a role model, teacher as 
an orchestra leader, and teacher as a motivator.

\subsection{Data Triangulation}

To validate the credibility of the data based on the observations and interview, the study used the data triangulation technique and compared the findings to

identify how the data from the observations are relevant to the interview.

Table 4.1 Classroom Observation Checklist

\begin{tabular}{|c|c|c|c|c|}
\hline No. & Items & Yes & No & Remarks \\
\hline \multirow[b]{2}{*}{1.} & \multirow[b]{2}{*}{ The teacher instructs in English. } & \multirow[b]{2}{*}{$\checkmark$} & & The whole lesson \\
\hline & & & & $\begin{array}{l}\text { Ask the students to sing and make an act of } \\
\text { "feeling hungry doo..doo..doo feeling you". }\end{array}$ \\
\hline 2. & $\begin{array}{l}\text { The teacher gives feedback to students in } \\
\text { English. }\end{array}$ & $\checkmark$ & & Looking to the individual task. \\
\hline 3. & $\begin{array}{l}\text { The teacher checks students' } \\
\text { comprehension in English. }\end{array}$ & $\checkmark$ & & $\begin{array}{l}\text { Ask questions to the students when they } \\
\text { presented. }\end{array}$ \\
\hline \multirow[t]{2}{*}{4.} & \multirow[t]{2}{*}{$\begin{array}{l}\text { The teacher explains new words in } \\
\text { English. }\end{array}$} & $\checkmark$ & & $\begin{array}{l}\text { Explain the word steals- taking other student's } \\
\text { things without permission. }\end{array}$ \\
\hline & & $\checkmark$ & & $\begin{array}{l}\text { Ask the students to do a thinking map about the } \\
\text { cat's feelings. }\end{array}$ \\
\hline 5. & $\begin{array}{l}\text { The teacher discusses tasks given in } \\
\text { English. }\end{array}$ & & & $\begin{array}{l}\text { The teacher gave the last exercise (rearranging) } \\
\text { to the students to write a number and write them } \\
\text { in a paragraph based on the story posted on the } \\
\text { board. }\end{array}$ \\
\hline 6. & $\begin{array}{l}\text { The teacher translates the instruction in } \\
\text { L1. }\end{array}$ & & $\checkmark$ & \\
\hline 7. & $\begin{array}{l}\text { The teacher sets rules when assigning } \\
\text { group activities. }\end{array}$ & $\checkmark$ & & $\begin{array}{l}\text { Discussed quietly } \\
\text { Model the map and ask the students to do the } \\
\text { map. }\end{array}$ \\
\hline 8. & $\begin{array}{l}\text { The teacher monitors the students during a } \\
\text { group activity. }\end{array}$ & $\checkmark$ & & Go group by group \\
\hline 9. & $\begin{array}{l}\text { The teacher penalizes the students if they } \\
\text { make a mistake. }\end{array}$ & & $\checkmark$ & \\
\hline \multirow[t]{2}{*}{10.} & \multirow[t]{2}{*}{ The teacher praises the students. } & \multirow[t]{2}{*}{$\checkmark$} & & $\begin{array}{l}\text { The teacher says very well after the students } \\
\text { read. }\end{array}$ \\
\hline & & & & Ask students to give a clap to themselves. \\
\hline \multirow{4}{*}{11.} & \multirow{4}{*}{ The teacher gives rewards to students. } & \multirow{4}{*}{$\checkmark$} & & $\begin{array}{l}\text { Teacher gave the students rewards (pencil) when } \\
\text { students read the story with actions. }\end{array}$ \\
\hline & & & & $\begin{array}{l}\text { Teacher gave stickers to the students in the } \\
\text { groups that showed cooperation. }\end{array}$ \\
\hline & & & & $\begin{array}{l}\text { Teacher gave a sticker to the group that } \\
\text { presented first, second, and third. }\end{array}$ \\
\hline & & & & $\begin{array}{l}\text { Lastly, the teacher gave a presentation to a boy } \\
\text { and two girls. }\end{array}$ \\
\hline 12. & $\begin{array}{l}\text { The teacher corrects the students' } \\
\text { mistakes. }\end{array}$ & $\checkmark$ & & \\
\hline 13. & $\begin{array}{l}\text { The teacher emphasizes to the students to } \\
\text { use English. }\end{array}$ & $\checkmark$ & & $\begin{array}{l}\text { The teacher asks the students to discuss in } \\
\text { English by saying, "English please. This is an } \\
\text { English class." }\end{array}$ \\
\hline
\end{tabular}

The table above presents the findings from the observations checklist. There are also field notes indicating the activities during the observations in an audio-lingual classroom for each item observed. The 
checklist from the observations and field notes shows three themes of activities performed by the teacher in an audio-lingual classroom: the teachers' roles in an audio-lingual classroom; teacher as a role model, teacher as an orchestra leader and teacher as a motivator.

In addition, the findings from the interview indicate that the teacher perceived three roles in an audio-lingual classroom to reduce the interference of L1 in learning L2. The interview findings show that the teacher highlighted the roles of a teacher in an audio-lingual classroom as a role model. The teacher stated that "in an audio-lingual classroom, I provide students with repetition, language content models, and provide them with the context of learning (grammar in context)".

Regarding how a teacher acts as an orchestra leader in an audio-lingual classroom, the teacher stated "controlling students' language behaviour". This indicates that the teacher acts as an orchestra leader by correcting the students' language mistakes. The teacher also reflected on how a teacher performs as a motivator in an audio-lingual classroom to reduce the interference of L1 in learning L2. The teacher stated that "direct the students to the language and respond positively positively". This shows that the teacher performs as a motivator by positive reinforcement of the students' response in an audiolingual classroom.

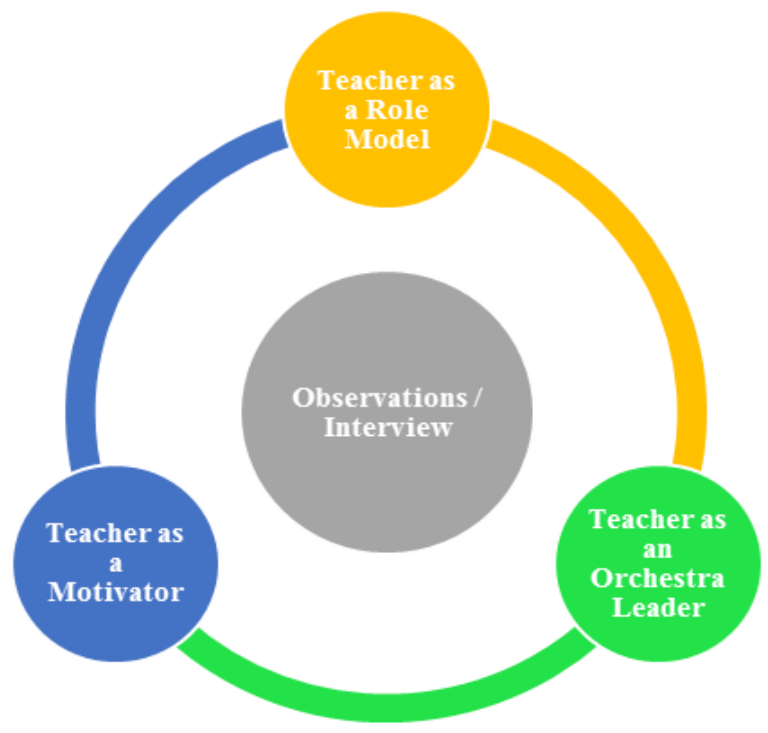

Figure 4.1 Data Triangulation

The figure above indicates the triangulation of the findings from data sources that shows that both observations and interviews lead to the same result. Therefore, the study confirms the principle of validation in scientific research and discusses the findings thematically below.

\subsubsection{Teacher as a Role Model}

According to O'Malley and Chamot (1995), the role of a language teacher is to model the language function. In this study, the finding from observations and interviews shows that the teacher acts as a role model in teaching L2. The teacher models L2 throughout the class. The instructions are giving entirely in L2. The discussions of the tasks are also illustrated in L2. The teacher also provides explanations in L2. For example, the teacher explained, "the word steal as taking other student's thing without permission". Adding to it, the teacher also perceived that teaching and learning must be conducted in L2 to promote the use of L2 and said that "students learn best from example, so I try to speak in English as much as I can inside or outside the classroom". Directly, this will reduce the interference of L1 inside or outside of the classroom when learners are communicating with the L2 teacher.

Furthermore, the teacher also modelled L2 through the drilling and repetition techniques in the story reading stage. In this Audio-lingual classroom, drilling (repetition) is one of the key principles as habit formation of the language. This is supported by Larsen-Freeman and Anderson (2018) that learning L1 is a process of habit formation; the more often something is repeated, the stronger the habit and the greater the learning. The finding from the observations shows that the teacher repeated the song with actions many times so that the students infused the formation of the language learning. The teacher also said, "I usually use drilling technique only for grammar" in the interview. This finding mirrors the research conducted by Shafie and Nayan (2010) in the tertiary level of English Education stated that the roles of University English Teachers are role models. Studies also indicated that traditional teaching and learning approaches are also intensively substituted with the new technology-integrated teaching and learning schemas, which shifts the roles of the teachers, particularly during the Covid-19 pandemic (Rahim \& Bilal Ali, 2021).

\subsubsection{Teacher as an Orchestra Leader}

Larsen-Freeman and Anderson (2018) stated that teachers should be like orchestra leaders conducting, guiding, and controlling the students' behavior in the target language. The finding of the current study also shows the role of the teacher as an orchestra leader where the teacher controls students' language behaviour by conducting the lesson in L2, guiding the students to use L2 and controlling the students", behaviour in the target language. Based on the observations, the teacher controlled the language used (L2) by the students during the class. For instance, the teacher asked the students to discuss English by saying, "English please. This is an English class". Besides, the teacher also ensures the students employ L2 in the lesson where the teacher said that she does not encourage them to speak in L1 and encourage the learners to use L2. These are the teacher excerpts 
from the interview "Yes, firstly, I don't encourage them to speak in their mother tongue", "Secondly, I encourage them to speak in English even though they make mistakes".

In addition, the role of the teacher is also to guide the students to use L2 as the teacher corrects the students' sentences by asking them to repeat the correct sentence. The excerpt from the interview is " $I$ will just correct their sentence or I will repeat their sentence back using the correct sentence structure and I ask them to ask me back". The teacher also controlled the students' behaviours in L2 to ensure that the students speak L2 in the classroom by reminding them. The teacher said, "If they speak Bahasa Malaya...eeeeermmm. I usually don't allow them to speak in Malay. But I will remind them". Thus, the result from the observations and interview shows that the teacher acts as an orchestra leader in reducing the interference of L1 in an audio-lingual classroom.

\subsubsection{Teacher as a Motivator}

In an audio-lingual classroom, the use of positive reinforcement is encouraged. It is to boost the student's confidence to develop the second language. Larsen-Freeman and Anderson (2018) stated that positive reinforcement helps the students to develop correct habits. The findings from the observations and interview show the teachers' roles as a motivator. The teacher uses positive reinforcement like giving compliments and rewards to the students. It is to reinforce the formation of L2 patterns among the learners in the lesson. During the observation, the student's responses are positively reinforced by giving compliments and rewards. The teacher complimented the learners by saying "very good" after the students read. The teacher also asked students to clap their hands when their classmates actively participated in the presentation. The teacher also gave pencils as a reward when the students read the story. The teacher gave stickers to the group after the presentation. Teachers also gave set stationery to three of the students for completing their tasks early.

This shows that the students are motivated in using L2 all the time in the lesson. During the interview, the teacher also said that "I usually give a compliment to make learners see more motivated to use English". The teacher also added, "I usually will give them like sticker first if they can collect like ten stickers, they will get one reward". Compliments and rewards are positive reinforcement to the students (LarsenFreeman \& Anderson, 2018). A study on second language speaking anxiety among Malaysian postgraduate students at a faculty of education revealed that students lack motivation while speaking in English (Badrasawi et al., 2020). Therefore, the current study's findings also indicate that the teacher acts as a motivator since the teacher is directing the students to use L2 by positive reinforcement. As a result, the teachers' roles are highlighted as motivators.

\section{Conclusion}

The study explored the teachers' roles in reducing the interference of L1 in an audio-lingual classroom. It has also integrated the underpinning theories to clarify how the interference of L1 impacts learning L2. The observations and interview are compared for validating the findings and triangulation purposes. The results concluded the teachers' roles as a role model, as an orchestra leader, and as a motivator to reduce the interference of $\mathrm{L} 1$ in learning $\mathrm{L} 2$ by applying an audio-lingual method. This contributes to the reduction of using L1 in teaching L2 classrooms since L1 negatively impacts learning L2. Therefore, the study recommends that prospective educators and language experts consider their potential roles in an audiolingual classroom.

\section{Acknowledgement}

This research was not possible without the help of our fellow friends at UTM Malaysia. Therefore, we thank our colleagues in UTM and the teacher and the students of the primary school in Johor Bahru who have provided insight and expertise that greatly assisted the research, although they may not agree with all of the interpretations/conclusions of this paper.

\section{References}

Badrasawi, K. J., Solihu, A., \& Tunku Ahmad, T. B. (2020). Second language speaking anxiety among malaysian postgraduate students at a faculty of education. International Journal of Education and Literacy Studies, 8(2), 54. https://doi.org/10.7575/aiac.ijels.v.8n.2p.54.

Brown, H. D. (2001). Teaching by principle and interactive approach to language pedagogy. New York: Longman Inc.

Burnkart, G. S. (1998). Spoken language: what it is and how to teach it. White Plains, NY: Longman.

Christine, M. (2007). Being able to speak English is not the same as being an outsider: Narratives of complexities of ELT. Chiang Payap: University of Mai.

Clarke, V. \& Braun, V. (2013). Teaching thematic analysis: overcoming challenges and developing strategies for effective learning. The Psychologist, 26(2), 120-123.

Creswell, J. W., \& Poth, C. N. (2017). Qualitative inquiry and research design: choosing among five approaches. Sage publications.

Ellis, R. (1994). The study of second language acquisition. Oxford: Oxford University Press. 
Elmusharaf K. (2012). Qualitative sampling techniques. training course in sexual and reproductive health research. Geneva.

Hashemi, A., \& Kew, S. N. (2020). the effects of using blended learning in teaching and learning English: A review of literature. International Journal of Eurasia Social Sciences, 18(4),173179.

Harari, Y., N. (2019). 21 Lessons for the 21st century. London: Vintage. Print.

Hornby, A. S. (2000). Principles of language Teaching. Oxford: Oxford University Press.

Krashen, S. (1985). Second language acquisition. New York: Routledge.

Krashen, S. D., \& Terrell, T. D. (1983). The natural approach language acquisition in the classroom. New York: Pergamon Press.

Larsen-Freeman, D., \& Anderson, M. (2018). Techniques and principles in language teaching. Oxford: Oxford University Press.

McDonough, J., \& McDonough, S. (1997). Research Methods for English language teachers. London: Arnold.

Miles, M. B., \& Huberman, A. M. (1994). Qualitative data analysis an expanded sourcebook. Thousand Oaks: CA Sage Publications.

Mitchell, F. \& Myles. A. (2004). Language arts \& disciplines. Oxford: Oxford University Press.

Mohammadi, T., Seraj, M. Y., Ibrahim, H., \& Abdul Hadi, N. F. (2019). the purposes of codeswitching and teachers' perceptions toward code-switching in Malaysian primary schools. International Journal of Engineering and Advanced Technology, 9(1), 1532- 1536. https://doi: 10.35940/ijeat.A1303.109119.

Nita. A., \& Syafei, B. (2012). Classroom action research for test repository. IAIN Salatiga.

Nunan, D. (1992). Research methods in language learning. Cambridge: Cambridge University Press.

O'Malley, J. M., \& Chamot, A. U. (1995). Learning strategies in second language acquisition. New York: Cambridge University Press.

Pennycook, A. (1994). The cultural politics of english as an international language. Unicamp: John Robert Schmitz.

Phillipson, R. (1994). English for globalization. New York: ICEA Press.

Rahim, M. N., \& Sandaran, S. C. (2020). EFL teachers' perceptions of the barriers and opportunities for implementing elearning at Afghanistan universities. Universal Journal of Educational Research, 8(11C), 97-104. https://doi.org/10.13189/ujer.2020.082311.

Rahim, M. N. (2021). Post-pandemic of covid-19 and the need for transforming education 5.0 in Afghanistan higher education. Utamax: Journal of Ultimate Research and Trends in Education, 3(1), 29-39. https://doi.org/10.31849/utamax.v3i1.6166.

Rahim. M.N., \& Zare. A. (2021). A critical review of the impacts of digital citizenship on teachers and students' educational development. International Journal of Multidisciplinary: Applied Business and Education Research, 2(7), 557-564. https://doi:10.11594/ ijmaber.02.07.01.

Rahim, M. N., Mohammadi, T., \& Hashemi, A. (2021). A critical evaluation of the twelfth grade English language textbook for Afghanistan high schools. Elsya: Journal of English Language Studies, 3(2), 67-77. https://doi.org/10.31849/elsya.v3i2.6295.

Rahim, M. N., \& Ali, M. B. (2021). The effect of using social media on academic performance of faculty members during covid-19 pandemic. Utamax: Journal of Ultimate Research and Trends in Education, 3(2), 106-114. https://doi.org/10.31849/utamax.v3i2.5934.

Richards, J. C. \& Rodgers, T.S. (2001). Approaches and methods in language teaching. London: Cambridge University Press.

Saricoban, A. (2016). Foreign language teaching practicum beliefs of student teachers. Dil ve Dilbilimi Çalışmaları Dergisi, 12(1), 166-176.

Shafie, L. A., \& Nayan, S. (2010). The roles of university english teachers in Malaysia. Journal of Language Teaching and Research, 262-265.

Tavakoli, P. (2017). Is fluency being neglected in the classroom? Tehran: SAMT. 